\title{
A histochemical investigation on the human sweat glands, with special references to the differential stainings, between eccrine and apocrine glands, by means of the enzymatic activities of the alkaline phosphatase, adenosine triph $\approx$ sphatase and 5-nucleotidase
}

\author{
By \\ Haruo Machida, Yoshie Masuda and Sadao Kobayashi \\ Department of Anatomy, School of Medicine, \\ Keio University, Shinjuku, Tokyo, Japan \\ (Director: Prof. Dr. T. Tanig u chi)
}

\begin{abstract}
Introduction
There are numerous histochemical investigations on the enzymatic activitities of the sweat glands, namely alkaline and acid phoaphatase (F is her and G li c k, 1947 ; B un ting, W is lo ck i et Dempsey, 1948; She lle y et M e s c on, 1952), non-specific esterases (M o n ta g n a, 1955), specific cholinesterase (A a v i k, 1955 ; $\mathrm{Hurley}$, Shelle y et Koelle, 1953), Phosphorylase (Y a s u a et al., 1958), succinic dehydrogenase (M o n t a $\mathrm{n}$ a and F or m is a no, 1955), monoamine oxidase ( $\mathrm{Y}$ a s u d and $\mathrm{M}$ ont a g $\mathrm{na}, 1960$ ) and chondrosulfatase ( $\mathrm{O} \mathrm{h} \mathrm{m} \mathrm{u} \mathrm{r} \mathrm{a} \mathrm{and} \mathrm{Y}$ a sod a, 1960). Both kinds, eccrine sweat gland (e-gland) and apocrine siweat gland (a-gland) were differentiated from each other by the differences in the distributions of glycogen, in those of $\mathrm{SH}$ groups, in those of RNA, in those of protein and in those of enzymes, namely alkaline and acid phosphatase, non-specific esterases, succinic dehydrogenase, phosphorylase and chondrosulfatase. In this paper the authors have studied the enzymatic activities of alkaline phosphatase, adenosine triphosphatase (ATPase) and 5-nucleotidase to look for the difference between the e-gland and the a-gland, and between the clear cell (the basal cell) and the dark cell (the superficial cell) in the e-gland.
\end{abstract}




\section{Materials and Methods}

The materials used are pieces of the skin from human axilla. The tissues were fixed with cold acetone, embedded in paraffin and cut in sections of $5 \mu$ in thickness. Go mor i's revised method for the alkaline phosphatase (1952), the $\mathrm{Takeuchi}$ and $\mathrm{Ohkawa-}$ $r$ a's method (1952) for the ATPase and the McManus, Lupton and Harden's method (1952) for the 5-nucleotidase were employed as staining procedures. As control in each reaction, negative results were examined by applying the solutions without the substrates; i.e. sodium glycerophosphate, adenosine triphosphate and adenosine monophosphate.

\section{Observations}

1. Alkaline phosphatase (Fig. 1, 2, 3, 4 and 5).

The sites of enzymatic activities indicate black coloration. The enzymatic activities of the e-gland are stronger than those of the a-glands (Fig. 1).

i) The secretory portion of the e-gland (Fig. 1).

The strongest enzymatic activities are observed in the cytoplasm of the clear cell, the myoepithelial cell and along the basement membrane (Fig. 1). Especially, intensely positive reaction is seen in the intercellular canaliculi of the clear cells. The dark cells are less strongly stained than the clear cells. Both kinds of the glandular cells have unreactive nuclei.

ii) The secretory portion of the a-gland (Fig. 2, 3 and 4).

The myoepithelial cell and the basement membrane have strong enzymatic activity, while the glandular cells have weak enzymatic activities (Fig. 2 and 3). Also the cytoplasm of the glandular cells is more strongly stained in the supranuclear area than in the infranuclear regions (Fig. 3). The nuclei of the a-glands are negative to the alkaline phosphatase reaction.

iii) The excretory ducts (Fig. 5).

The excretory ducts are faintly stained. There are no difference of the enzymatic activities between the internal and the external cell layer.

2. Adenosine triphoshatase (Fig. 6, 7, 8 and 9).

The sites of the enzymatic activities indicate black coloration. 
The enzymatic activities are stronger in e-glands than in a-glands (Fig. 6 and 7).

i) The secretory portion of the e-glands (Fig. 6).

The most intensely stained sites are the dark cells, the myoepithelial cells and the basement membrane (Fig. 6). The cytoplasm of the dark cell is diffusely stained, but the cytoplasm of the clear cell is merely stained in the surrounding region of the nucleus. The nuclei of both kinds of the glandular cells, especially the nuclear membranes are strongly positive to ATPase reaction.

ii) The secretory portion of the a-glands (Fig. 7).

The sites which are intensely stained are the apical cytoplasm and the nucleus of the gland cell, the myoepithelial cells and the basement membrane (Fig. 7). Therefore, the supranuclear region show a stronger stainability than the infranuclear region. Especially, the enzymatic activities in the myoepithelial cells are recognized as numerous black-lines.

iii) The excretory ducts (Fig. 8 and 9).

The excretory ducts of both kinds of the sweat glands are positive to the ATPase reaction (Fig. 8 and 9). There are no differences of the enzymatic activities between the internal and the external cell layers. Generally, the stronger stainabilities exist in the nuclear membrane.

3. 5-nucleotidase (Fig. 10, 11 and 12).

The enzymatic activities are more intensive in the e-gland than in the a-gland (Fig. 10 and 11).

i) The secretory portion of the e-gland (Fig. 10).

The cytoplasm of the clear cell is not completely stained. On the contrary, the cytoplasm of the dark cell is diffusely stained (Fig. 10). Moreover, the nuclei of both kinds of the glandular cells show strong enzymatic activities. There are strong stainabilities both in the myoepithelial cells and in the basement membrane (Fig, 10).

ii) The secretory portion of the a-gland (Fig. 11).

The strongest stainability was found in the nuclei of the gland cells, the myoepithelial cells and the basement membrane. The cytoplasm of the gland cell is diffusely stained. There are no differences of the enzymatic activities between the supranuclear and the infranuclear regions of the glandular cytoplasm.

iii) The excretory ducts (Fig. 12). 
The cytoplasm of the internal cell is moderately stained, but the cytoplasm of the external cell is unstained. The nuclei of both kinds of cells are intensely stained (Fig. 12).

\section{Discussion}

$\mathrm{Sc}$ h i e f f e r d e cker (1922) divided the sweat glands into the e-gland and the a-gland in respect to the difference in the secretion modus, in the development of the sweat gland and in the distribution of the body. Moreover, I to (1944) showed that the e-glandular cells consisted of two kinds of cells which were differentiated from each other by the difference of the distribution pattern of mitochondria, the form of the Golgi apparatus, the number of the secretory granules, and by the existence of the intercellular canaliculus. On the other hand, histochemically, the chemical differences between the e-gland and the a-gland, and between the clear cell and the dark cell in the e-gland were demonstrated. Namely these chemical substances are glycogen (M o n t a g n a, 1951; I t o, 1949), RNA (M o n t a g n a, 1953 ; I t o, 1951), Indophenol positive substances (Yas u da, 1960), SH groups (Montagna, 1964; Machida et al., 1962), protein ( $\mathrm{Y}$ a s uda, 1960; M a c hida et al., 1962), alkaline and acid phosphatase (B unting et al., 1948; Shelley et al., 1952), non-specific esterases (M o n t a g n a, 1955), phosphorylase (Y a s u d a et al., 1958) and chondrosulfatase (O h m u r a et al., 1960) etc. In addition, it may be possible to differentiate between the a-gland and the e-gland, and between the clear cell and the dark cell in the e-gland tubule also by means of the enzymatic activities as reported in this report. For the flrst time, R o b i s o n (1923) demonstrated the alkaline phosphatase activity in the osseous tissue. Moreover, Fisher et G lick (1947), B unting et al. (1947) and S helle y et M e s c on (1952) ascertained the alkaline phosphatase in the sweat glands. The distributions of the alkaline phosphatase investigated in the sweat glands corresponded with the results of the studies both by Shelley et $\mathrm{Mescon}$ and by Bunting et al., namely the alkaline phosphatase activities concentrated in the basal regions of the secretory portions including the myoepithelial cells. According to the reports of $\mathrm{I} \mathrm{h} \mathrm{j} \mathrm{i} \mathrm{m} \mathrm{a} \mathrm{(1958)} \mathrm{and} \mathrm{G} \mathrm{o} \mathrm{to} \mathrm{(1961),} \mathrm{the} \mathrm{alkaline}$ phosphatase in the e-gland of the human embryo concentrates in the apex of the clavate-like primordium and concentrates both in the dark cell and in the myoepithelial cells after the formation of 
the lumen. According to the report of $\mathrm{Yas} \mathrm{u} i$ (1960), the distribution of the alkaline phosphatase is found both in the dark cell and in the clear cell from the new born child to the child of 6 years of age. In addition, it is said, that after the aze of 8 years the alkaline phosphatase activity of the clear cell is stronger than that of the dark cell, and the distribution of this enzyme at the age of 15 years resembles that in the adult. Moreover, according to $\mathrm{Y}$ as u i's report, the alkaline phosphatase activities can not be found in the a-gland till the age of 6 years, and at the age of 8 years it is the first time that the weakest activities can be found. The distribution of the alkaline phosphatase in the sweat gland is variable in the variation of age. According to the report of $\mathrm{K}$ os h i k a w a (1958), the alkaline phosphatase activity in the e-gland of the lower abdomen of a woman is stronger in the clear cell, than in the dark cell. Kawak ami (1959), Furusawa (1959) and M a t s u moto (1960) demonstrated the alkaline phosphatase in the e-gland of the sole of the monkey and in the a-gland of the dorsal portion of the foot. According to their reports, the distributions of the alkaline phosphataes of the monkey almost resemble those of a man, namely the enzymatic activities of the e-glands are stronger in the myoepithelial cell and in the clear cell, and those of the a-glands are more intensive in the myoepithelial cell and in the basal cytoplasm of the glandular cell. After the injections of adrenalin and pilocarpine, the alkaline phosphatase activities increased both in the agland and in the e-gland of the monkey ( $\mathrm{K} \mathrm{a} \mathrm{w} \mathrm{a} \mathrm{k} \mathrm{a} \mathrm{m} \mathrm{i,} 1959$; $\mathrm{M} \mathrm{a}-$ t s u m o t o, 1960). Even though these changes are induced by means of the injections of drugs, it may be possible that the alkaline phosphatases are greatly concerned in the secretion and the sweating of the sweat glands. According to the report of $\mathrm{M}$ o $\mathrm{n} t \mathrm{a} \mathrm{g} \mathrm{n}$ a (1956), the distribution of alkaline phosphatase toward the base of the cells and acid phosphatase at the apex suggests that one is related to the transfer of blood-borne nutritive material and the other to the transfer of the secretion to the lumen. These experimental histochemical results ( $\mathrm{Ka} \mathrm{w}$ a $\mathrm{k}$ a $\mathrm{m}$ i and $\mathrm{M}$ ats $\mathrm{u}$ moto) suggest that both e-gland and a-gland are innervated by both adrenergic ( $\mathrm{Y}$ as u d a et al., 1960) and by the cholinergic fiber (A a vi k, 1955). The nuclei of both kinds of glands are darkly stained in control test. In addition, the nuclei in glands are unstained by means of the Gomori's azo dye method. Generally speaking, the alkaline phosphatases are unlikely to be found in the nuclei. Lohmann (1934) and Szent- 
G y ö r g y (1951) have studied about the role of ATP as to the muscle contraction. It is said that ATPase is usually concerned with the ATP. However, the ascertainment of this myosine-ATPase remains still problematical (Enge l hard t and Li u b i mova, 1939; Baile y, 1942 ; Needham, 1942; Polis and Meyerhof, 1947). Recently, it has become evident that there is at least one other ATPase in

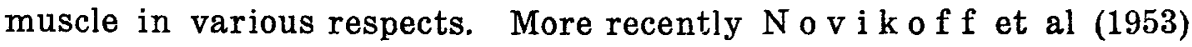
reported the fact that the mitochondrial fraction from the rat liver homogenate possesses a high specific activity for ATPase. The recent knowledge of enzymatic chemistry has made clear, that the mitochondria are associated with the enzyme system. According to the report of To nom u r a (1956), there are two kinds of ATPase, myosine-ATPase and the ATPase binding with the mitochondria, in the ATPase. The former is greatly concerned with the mechanism of the muscle contraction ( $\mathrm{L} \mathrm{i} \mathrm{u}$ b $\mathrm{m} \mathrm{ov}$ a and $\mathrm{Eng}$ e l h a r d t, 1939), and the latter occupies the important situation as the energy source in the living body ( $\mathrm{L}$ i p m a n n, 1941). G li c k and F is he r (1945 and 1946) flrst demonstrated the ATPase activity in the plant tissue by means of the histochemical method. T o g a r i (1960) demonstrated the distribution of ATPase in such fishes as the carp, the trout and the crustacea. According to Tog a r i's report, the ATPase activity in the muscle appears exclusively in the sarcoplasm rather than in the myofibrils. Also it is said that the localization of the ATPase is in complete accordance with the site of mitochondria. According to the reports of Ess ner et $\mathrm{Novik}$ of $\mathrm{f}$ (1958), the localization of the ATPase is in the plasma membrane of the liver cell, and that of the 5-nucleotidase is in complete accordance with the site of the nucleus of the leukocyte. According to the reports of the groups of the Harvard University, Dempsey and his cooperators, the distributions of the enzymes are variable in employing such substances as the substrates, like glycerphasphate, glucose-1-phosphate, adenyl acid in yeast, hexose diphosphate, ribonuclic acid and lecithin etc. And it is said that each substrate has an enzyme of itself (cited from Lis o n, 1954). According to the studies on the various organs of rabbits by $\mathrm{Take} \mathrm{u} \mathrm{chi}$ and $\mathrm{Oh} \mathrm{kawara} \mathrm{(1952}$ and 1953), the three kinds of the ATPase, the 5-nucleotidase and the alkaline phosphatase appear in a different distribution pattern from one another. Also the results we have investigated indicate that the three kinds of the alkaline phosphatase, the 5-nucliotidase and the ATPase are of different distributions from one another. 


\section{Conclusion}

1. The authors investigated on the localizaion of alkaline phosphatase, ATPase and 5-nucleotidase reactions in the e-glands and the a-glands of the human axilla.

2. The three kinds of the enzymatic activities are generally stronger in the e-gland than in the a-gland.

3. The secretory portion of the e-gland: The reaction of the alkaline phosphatase is stronger in the clear cell than in the dark cell. On the contrary, the activity of ATPase and 5-nucleotidase are stronger in the dark cell than in the clear cell. The myoepithelial cell and the basement membrane are strongly stained in three kinds of histochemical reactions.

4. The secretory portion of the a-gland: The sites of the strongest stainabilities by means of the three kinds of reactions are the myoepithelial cells and the basement membrane. The cytoplasm of the glandular cell is faintly stained. However, the apical cytoplasm is moderlately reactive by the two other reactions except the 5-nucleotidase reaction. The nuclei of the glandular cells are strongly stained only by 5-nucleotidase and the ATPase reactions.

5. The excretory ducts: The cells of inner and outer layers are clearly distinguished only by the 5 -nucleotidase reaction.

\section{Acknowledgement}

It is a pleasure to record our sincere thanks to Prof. Dr. T. $\mathrm{Tanig} \mathrm{u} \mathrm{chi}$ and Instructor Dr. K. Y a s u d for their kind criticisms and helpful guidance during the course of this work.

\section{References}

1) A a vik, O.R. 1955 : Cholinesterases in human skin. J. Invest. Dermat., vol. 24, pp. 103-106.

2) B a i le y, K. 1942 : Myosine and adenosine triphosphatase. Biochem. J., vol. 36, pp. 121-139.

3) Bunting, H., Wis lock i, G. B. and Dempsey, E. W. 1948: The chemical histology of human eccrine and apocrine sweat glands. Anat. Rec., vol. 100, pp. 61-77.

4) Engel hardt, W. A. and L i u bimova, M. N. 1939: Myosine and adenosine triphosphatase. Nature, vol. 144, pp. 668-669.

5) Essner, E., Novik of f, A. B. and M a s e k, B. 1958: Adenosine triphosphatase 
and 5-nucleotidase activities in the plasma membrane of liver cells as revealed by electron microscopy. J. Biophys. and Biochem. Cytol., vol. 4, pp. 711-716.

6) Fi is her, J. and G li ck, D. 1947: Histochemistry. XIX. Localisation of alkaline phosphatase in normal and pathological human skin. Proc. Soc. Exptl. Biol. Med., vol. 66, pp. 14-18.

7) Furusawa, H. 1959: A histochemical study on the sweat glands in the sole and dorsal portion of the foot of the monkey. Acta Anthropologia, Anthropohereditologia et Somatologica, Bd. 33, ss. 9-19 (Japanese).

8) Gomori, G. 1952: Microscopic Histochemistry. Principles and Practice. The University of Chicago Press, Chicago.

9) Goto, T., Ka g a, T. and O on o, T. 1961: Cytochemical studies of alkaline phosphatase and glycogen in eccrine sweat glands in the palm and the sole of the human embryo. Okajimas Fol. anat. jap., Bd. 37, ss. 247-258.

10) Hurley, H. J., Shelley, W. B. and Koelle, G. B. 1953: The distribution of cholinesterase in human skin, with special reference to eccrine and apocrine sweat glands. J. Invest. Dermat., vol. 21, pp. 139-147.

11) I h j i m a, A. and Iet a, T. 1958: A cytochemical study of the auricular sweat glands of the human embryo. Okajimas Fol. anat. jap., Bd. 31, ss. 419-426.

12) I to, T. 1944: Zytologische Untersuchungen über die ekkrinen Schweissdrüsen in menschlicher Achselhaut. Recent advance in medicine, VI., Nanjo-Shoten, Tokyo. (Japanese)

13) I to, T. and O h t a, T. 1949: A contribution to the study on the glycogen in the sweat glands. Seitai no Kagaku, vol. 1, pp. 146-148. (Japanese)

14) I t o, T., T such i ya, K. and I wash ige, K. 1951: Studien über die basophile Substanz (Ribonukleinsäure) in den Zellen der menschlichen Schweissdrüsen. Arch. hist. jap., vol. 2, pp. 279-287.

15) K a w a k a mi, Ch. 1959: A histochemical study on the sweat glands in the sole and dorsal portion of the foot of the monkey after pilocarpine injection. Okajimas Fol. anat. jap., Bd. 33, ss. 199-216.

16) Koshikawa, S. 1959: A histochemical investigation on the sweat glands of the lower abdomen of a woman. Okajimas Fol. anat. jap., Bd. 33, ss. 11-18.

17) Li pman n, F. 1941 : Advances in Enzymology, vol. 1, p. 99.

18) L i s o n, L. 1953: Histochimie et cytochimie animales. Principles et Méthodes. Gauthier-Villars, Paris.

19) Lohman n, K. 1934: Über die enzymatische Aufspaltung der Kreatinphosphorsäure; zugleich ein Beitrag zum Chemismus der Muskelkontraktion. Biol. Z., Bd. 271, ss. 264-277.

20) M a chida, H., M a sud a, Y. and Kob a y a shi, S. 1962: A histochemical investigation on the human sweat gland. Especially on mercuric bromphenol blue reaction, Chèvremont-Frédéric method and tetrazonium reaction. Okajimas Fol. anat. jap., Bd. 38, ss. 285-296.

21) Matsumoto, Sh., Yoshida, M. and Tateno, U. 1960: A cytochemical investigation on the sweat glands of the monkey. Okajimas Fol. anat. jap., Bd. 34, ss. 477-508.

22) Matsumoto, Sh. and Ohkura, Y. 1960: Cytochemical studies on the sweat glands of the monkey after pilocarpine injection. Okajimas Fol. anat. jap., Bd. 34, ss. 523-552.

23) M c M n u s, J.F.A. and Mow ry, R.W. 1960: Staining Methods. Histologic and Histochemical. Paul B. Hocber, Inc., New York. 
24) Montagna, W., Chase, E.B. and $\mathrm{Hamilt}$ on, J.B. 1951: The distribution of glycogen and lipids in human skin. J. Invest. Dermat., vol. 17, pp. 147-157.

25) Montagna, W., Chase, H.B. and Lobitz, W.C. 1952: Histology and cytochemistry of human skin. II. The distribution of glycogen in the epidermis, hair follicle, sebaceous glands and eccrine sweat glands. Anat. Rec., vol. 114, pp. 231-248.

26) Montagna,W., Chase, H. B. and Lobitz, W.C. 1953: Histology and cytochemistry of human skin. IV. The eccrine sweat gland. J. Invest. Dermat., vol. 20 , pp. $415-423$.

27) Montag $n$ a, W., E is en, A.Z., R a de $\mathrm{m}$ a che r, A.H. and $\mathrm{Ch}$ ase, H.B. 1954 : Histology and cytochemistry of human skin. VI. The distribution of sulfhydryl and disulfide groups. J. Invest. Dermat., vol. 23, pp. 23-32.

28) Montagna, W. and Formis a no, V. 1955: Histology and cytochemistry of succinic dehydrogenese activity. Anat. Rec., vol. 122, pp. 65-77.

29) Montag na, W. 1955: Histology and cytochemistry of human skin. IX. The distribution of non-specific esterases. J. Biophys. Biochem. Cytol., vol. 1, pp. 13-16.

30) Montagna, W. 1956: The structrue and function of skin. Academic Press Inc., New York.

31) Needh a m, D. M. 1942: The adenosine triphosphatase activity of myosine preparation. Biochem. J., vol. 36, pp. 113-120.

32) Novikoff, A. B., Podber, E., R y a n, J. and Noe, E. 1953 : Biochemical heterogeneity of cytoplasmic particles isolated from rat liver homogenate. J. Histochem. Cytochem., vol. 1, pp. 27-46.

33) O h m u ra, H. and $\mathrm{Ya}$ a oda, T. 1960: Histochemical investigation on the chondrosulfatase in the sweat glands of the human axilla. Okajimas Fol. anat. jap., Bd. 34, ss. 599-614.

34) O k a moto, K., U e d a, M. and M a eda, T. 1955 : Microscopic Histochemistry. 2nd edition, Igaku-Shoin, Tokyo. (Japanese)

35) Pearse, A.G.E. 1960: Histochemistry. Theoretical and Applied. J. \& A. Churchill, Ltd., London.

36) Polis, B. D. and Meye $\mathrm{r}$ hof, O. 1947: Studies on adenosine triphosphatase in muscle. I. Concentration of the enzyme on myosine. J. Biol. Chem., vol. 169, pp. 389-402.

37) Robi s o n, R. 1923 : Biochem. J., vol. 17, p. 286. (cited from Li s on 1953)

38) Schiefferdecker, P. 1922: Die Hautdrüsen des Menschen und der Säugetiere, ihre histologische und rassenanatomische Bedeutung sowie Musculus sexualis. Zoologia 77, H. 27, ss. 1-22. (cited from I to 1944)

39) Shelley, W.P. and Mescon, H. 1952: Histochemical demonstration of secretory activity in human eccrine sweat glands. J. Invest. Dermat., vol. 18, pp. 289-301.

40) Szent-Györgi, A. 1951: Chemistry of muscular contraction. 2nd edition, Academic Press, New York.

41) Takeuchi, T. and Ohkawara, T. 1952: Cytochemical study of Adension triphosphatase in blood and bone marrow cells. Med. and Biol., vol. 24, pp. 226-229. (Japanese)

42) Takeuchi, T. and Ohkawara, T. 1953: Histochemical study on 5-nucleotidase in animal tissues. Med. and Biol., vol. 25, pp. 123-126. (Japanese)

43) Takeuchi, T. and Ohkawara, T. 1953: Histochemical study of adension 
triphosphatase in rabbit tissues. Med. and Biol., vol. 26, pp. 224-226. (Japanese)

44) Tog a ri, Ch. and Uem a t su, H. 1960: Histochemical studies on the "Chiai" muscle (Red Muscle) of the Fish. I. The intracellular localization of adenosine triphosphatase activities and glycogens, with special reference to the function of the fish. Okajimas Fol. anat. jap., Bd. 35, ss. 27-40.

45) Tonomura, Y. 1956: Adenosine triphosphatase. The Method of Enzymatic Investigation. Vol. 2, Ist edition, Asakura-Shoten, Tokyo. (Japanese)

46) Y a s u da, K., Furu sawa, H. and O gat a, N. 1958: Histochemical investigation on the phosphorylase in the sweat glands of the axilla. Okajimas Fol. anat. jap., Bd. 31, ss. 161-170.

47) $\mathrm{Y}$ a s u d a, K. and M on t a $\mathrm{g}$ a, W. 1960: Histology and cytochemistry of human skin. XX. The distribution of monoamine oxidase. J. Histochem. Cytochem., vol. 8, pp. 356-366.

48) Y a su da, K. and Ni s h in o, Y. 1960: A cytochemical study on the sweat glands of the human axilla. On the indophenol reaction. Okajimas Fol. anat. jap., Bd. 36 , ss. 243-252.

49) Y a suda, K. and Ka ge moto, H. 1960: A cytochemical study on the sweat gland of the human axilla. On the coupled tetrazolium reaction. Okajimas Fol. anat. jap., Bd. 36, ss. 185-194.

50) Yasui, I. 1960: A histochemical investigation on the axillary sweat glands (eccrine and apocrine glands) during childhood in Japanese. Especially on alkaline and acid phosphatase. Okajimas Fol. anat. jap., Bd. 35, ss. 275-310.

\section{Explanations of Figures}

Fig. 1. The secretory portion of the e-gland (alkaline phosphatase reaction).

Fig. 2. The secretory portion of the a-gland (alkaline phosphatase reaction).

Fig. 3. The same as above.

Fig. 4. The same as above.

Fig. 5. The excretory duct and secretory portion of the e-gland (alkaline phosphatase reaction).

Fig. 6. The secretory portion of the e-gland (ATPase reaction).

Fig. 7. The secretory portion of the a-gland (ATPase reaction).

Fig. 8. The excretory duct (ATPase reaction).

Fig. 9. The excretory duct (the control of the ATPase reaction).

Fig. 10. The secretory portion of the e-gland (5-nucleotidase reaction).

Fig. 11. The secretory portion of the a-gland (5-nucleotidas reaction).

Fig. 12. The excretory duct (5-nucleotidase reaction). 
Plate I
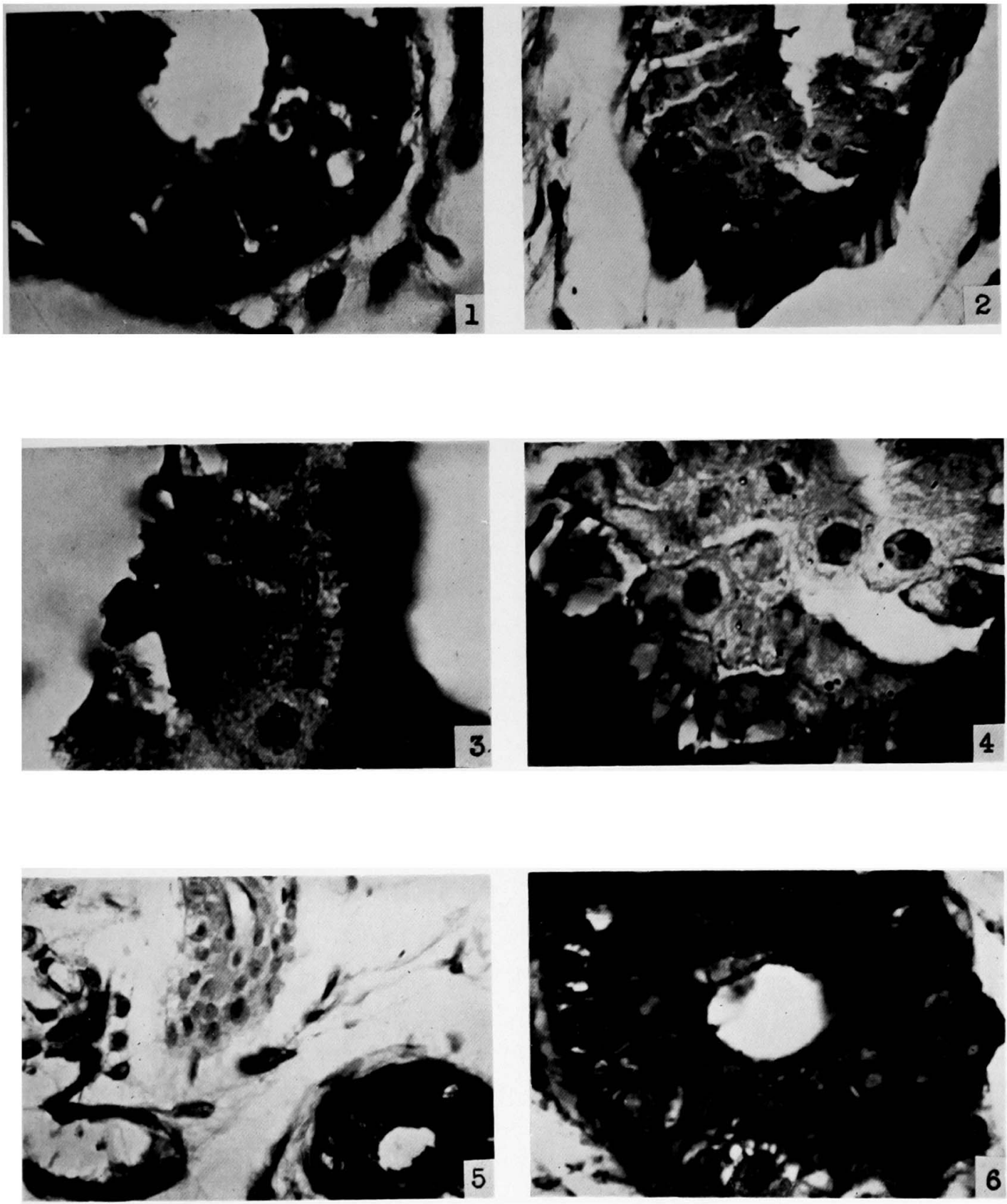

H. Machida, Y. Masuda and S. Kobayashi 
Plate II
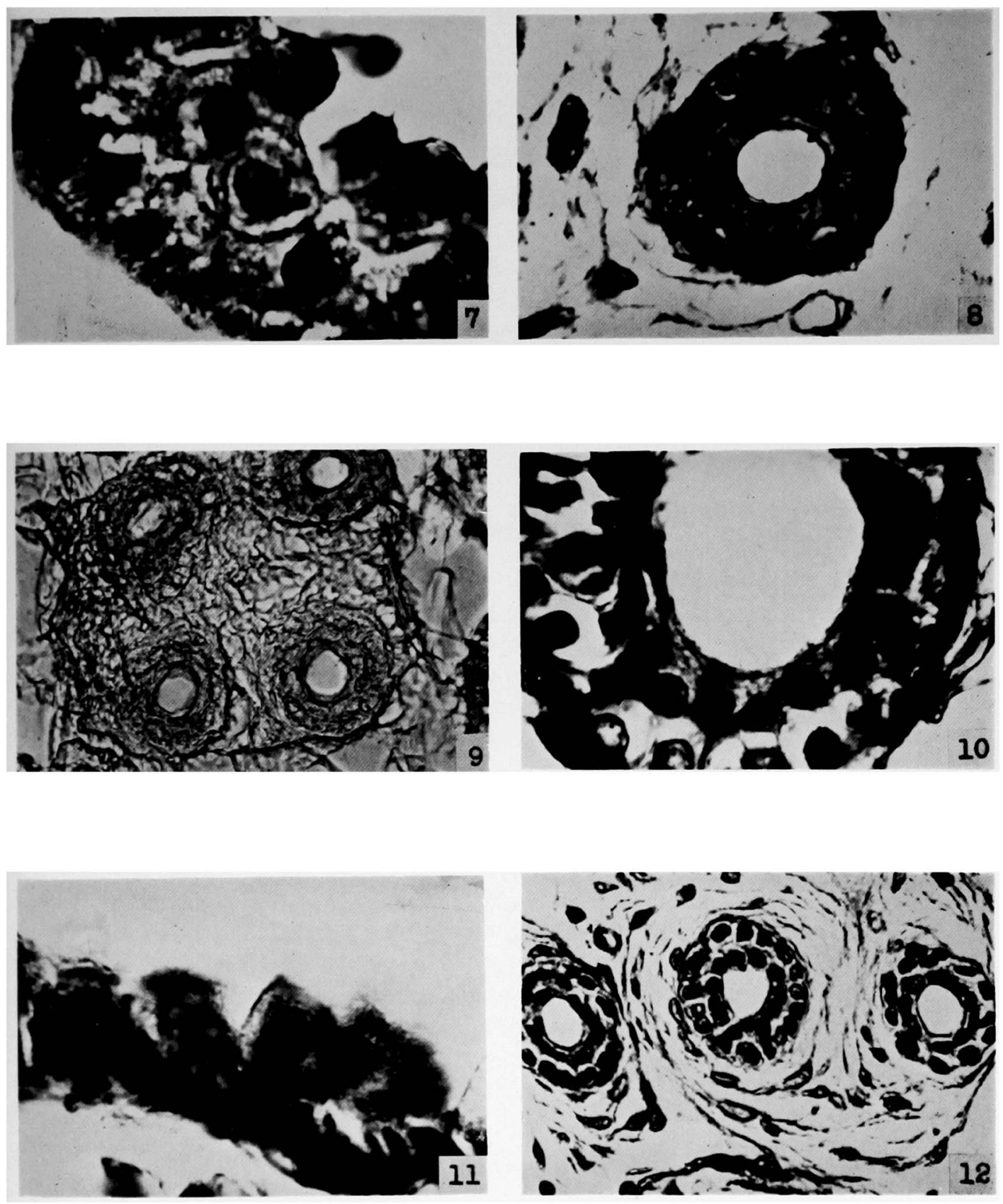

H. Machida, Y. Masuda and S. Kobayashi 